\section{Primjena društveno odgovornog marketinga u poslovanju malih i srednjih poduzeća ${ }^{1}$}

\section{Social responsible marketing in the business of small and medium-sized enterprises}

\section{Sažetak}

Ciljevi rada su utvrditi dimenzije i analizirati stupanj razvoja društveno odgovornog marketinga (DOM-a) malih i srednjih poduzeća (MSP-a) u Hrvatskoj te ispitati čimbenike koji utječu na vlasnike/menadžere MSP-a prilikom primjene DOM-a. Primijenjeno je kvalitativno istraživanje putem dubinskih intervjua ( $\mathrm{n}=16$ ), analize bilješki s terena, internetskih stranica poduzeća te izvješća poduzeća vezanim uz DOM. Rezultati istraživanja su pokazali kako su vlasnici/menadžeri MSP-a u RH većinom upoznati s pojmom i definicijom DOM-a, ali kako je primjena takvog poslovanja još u začecima. DOM-a je u najvećoj mjeri usmjeren prema potrošačima, zaposlenicima i lokalnoj zajednici, dok se ostale interesno-utjecajne skupine (dobavljači, konkurencija, okoliš, vladine organizacije i mediji) spominju tek od strane nekoliko ispitanika. MSP-a se međusobno razlikuju prema stupnju razvoja društveno odgovornog marketinga i dijele se u tri skupine: poduzeća koja minimalno odgovaraju principima DOM-a, poduzeća koja imaju poseban tim unutar svoje organizacije zadužen za smišljanje i provedbu takvih aktivnosti te poduzeća koja su svoje djelovanje utemeljila na principima održivosti i slijede in u svakoj svojoj odluci i akciji.

Ključne riječi: društveno odgovoran marketing, mala i srednja poduzeća, percepcija vlasnika/menadžera, Hrvatska

\section{JEL klasifikacija: M14, M31}

\section{Abstract}

The aim of this study is to determine the size and level of development of socially responsible marketing of small and medium-sized enterprises (SMEs), and to analyse factors that affect the application of such behaviour. 16 in-depth interviews with owners / managers from different activities of SMEs were conducted. Results show that they are acquainted with the concept of socially responsible marketing, but that the application in most companies is still in its infancy. Socially responsible marketing activities are mainly directed towards consumers, employees and the local community, while the secondary stakeholders (suppliers, competition, environment, Government organization and media), are mentioned only by a few of the surveyed SMEs. Companies differ according to the degree of development of socially responsible marketing: a) a minimum correspond to the principles of socially responsible marketing; b) have a special team responsible for devising and implementing activities, and c) their actions founded on the principles of sustainability and follow them in all their decision and

1 Rad je izrađen prema magistarskom radu Bradica,H.(2016) Aktivnosti društveno odgovornog marketinga u malim i srednjim poduzećima - Ekonomski fakultet Zagreb. Mentorica prilikom izrade magistarskog rada je bila doc.dr.sc. Ružica Brečić.
Doc.dr.sc. Ružica Brečić

Ekonomski fakultet Sveučilišta u Zagrebu E-mail: rbrecic@efzg.hr

\section{Hrvoje Bradica}

Zračna luka Zagreb d.0.0.

E-mail:hbradica@zag.aero

Doc. dr.sc. Mihovil Anđelinović

Ekonomski fakultet Sveučilišta u Zagrebu E-mail:mandelinovic@efzg.hr

\section{Asst. prof. Ružica Brečić, PhD}

Faculty of Economics and Business, University of Zagreb

E-mail: rbrecic@efzg.hr

\section{Hrvoje Bradica}

MZLZ - International Zagreb Airport Jsc. E-mail:hbradica@zag.aero

Asst. prof. Mihovil Anđelinović, PhD Faculty of Economics and Business, University of Zagreb

E-mail:mandelinovic@efzg.hr 
Brečić, R, Bradica, H., Anđelinović,M.

Primjena društveno odgovornog marketinga u poslovanju malih $\mathrm{i}$ srednjih poduzeća action. The most important factors for implementation of socially responsible marketing in SMEs are: vision of the owners / managers of SMEs; company size and activity.

Keywords: socially responsible marketing, small and medium sized enterprises, the manager's/owner's perception, Croatia

JEL classification: M14, M31

\section{Uvod}

Društvena odgovornost poduzeća privlači rastući interes širom svijeta, te je postala jedna od glavnih tema kako javnih rasprava tako i korporativnih planova (Skarmeas i Leonidou, 2013.; Sobczak i Havard, 2015.). Nagli rast interesa proizlazi iz nekoliko činjenica: interesno-utjecajne skupine iskazuju povećan interes da budu bolji članovi društva, potreba za većom transparentnošću poslovanja trgovačkih društava,kao i kompleksnosti globalnog poslovnog okruženja (Jamali i Mirshak, 2007.).

U skladu s time, menadžeri polažu sve više pažnje društveno odgovornom poslovanju (DOP-u) (Skarmeas i Leonidou, 2013.). Koncept DOP-a pretežito se tretira kao obveza poduzeća koja izlazi iz okvira gospodarskih i pravnih obaveza da bi obuhvatila volontersku dimenziju u smislu etičkih ili filantropskih odgovornosti (Carroll, 1991.), odgovor poduzeća na trenutna ili buduća očekivanja dioničara (Sobczak i Havard, 2015.; Oberseder, Schlegelmich i Murphy, 2013.). DOP je stoga postala matična, vrlo istaknuta i uobičajena aktivnost poduzeća, a ne više sporedna aktivnost koju provodi nekoliko poduzeća s dobrim financijskim zaleđem (Skarmeas i Leonidou, 2013.) Takvo povećano zanimanje potaklo je i znatan broj istraživanja koncepta DOP-a koja obuhvaćaju područja koja se preklapaju, kao što su korporativno građanstvo i održivost, teorija korporativnih dionika te poslovna etika (Lin-Hi i Muller, 2013.).

Predmet istraživanja je društveno odgovoran marketing u poslovanju malih i srednjih poduzeća u tranzicijskoj hrvatskoj ekonomiji. Ciljevi istraživanja su utvrditi dimenzije $i$ analizirati stupanj razvoja društveno odgovornog marketinga malih i srednjih poduzeća te utvrditi čimbenike koji utječu na vlasnike/menadžere MSP-a prilikom primjene DOM-a.
Literatura koja se bavi ovom tematikom, do sada istražuje vrste i važnost društveno odgovornih aktivnosti, motivaciju koja stoji iza društveno odgovornih aktivnosti poduzeća, društveno odgovornu praksu koja povećava korporativnu učinkovitost, mjeru do koje poduzeća "posluju dobro čineći dobro" te najbolje načine suradnje $s$ dioničarima i odgovaranje na njihove zahtjeve (Basu i Palazzo, 2008; Lin-Hi i Muller, 2013.; Öberseder, Schlegelmilch i Murphy, 2013.). Nekolicina studija na ovom području istraživanja sugerira da razne poslovne koristi koje se uz to vežu daju poticaj poduzećima da se angažiraju na polju DOP-a. Neke od koristi uključuju organizacijsku privlačnost potencijalnim zaposlenicima, povećanje osjećaja ponosa, predanosti i morala kod zaposlenika, povećan osjećaj zadovoljstva i lojalnosti kod potrošača, povećanje reputacije i ugleda poduzeća, poboljšan financijski efekt te konkurentsku prednost (Du i sur., 2010.; McShane i Cunningham, 2012.; Skarmeas i Leonidou, 2013.). U skladu s time, DOP je danas daleko relevantnije kao strategija rasta nego kao filantropsko nastojanje ili kao usklađenost $s$ propisima (Pohle i Hittner, 2008.).

Drugi smjer istraživanja DOP-a posvećen je ispitivanju percepcije potrošača 0 društveno odgovornim aktivnostima poduzeća (Öberseder, Schlegelmilch i Murphy, 2013.), te učinku koji strategije DOP-a imaju na različite interesno-utjecajne skupine (Sobczak i Havard, 2015.). Percepcija dionika u ovim radovima odnosi se na čelnike nevladinih organizacija, članove vlada (Beckman i sur., 2009.), menadžere (Öberseder, Schlegelmilch i Murphy, 2013.) i zaposlenike (McShane i Cunningham, 2012.). Navedena istraživanja ističu važnost angažmana dioničara pri istraživanju autentičnosti različitih društveno odgovornih aktivnosti koje prelaze okvire gospodarskih i zakonskih obveza poduzeća. Štoviše, naglo rastući broj istraživanja usredotočuje se na problem korporativne društvene 
neodgovornosti (Lin-Hi i Muller, 2013.; Skarmeas i Leonidou, 2013.). Ističe se sve veći broj slučajeva gdje neka poduzeća potrošačima daju netočne informacije 0 proizvodu, slučajevi kršenja ljudskih prava, financijski skandali, prevare i obmane, ekološke katastrofe, zagađenje voda, društveni prijestupi te namještanje cijena poduzeća koja javno proklamiraju društveno odgovorno ponašanje, povećavaju sumnjičavost korporativnih dionika u odnosu na razložnost i autentičnost takvih društveno odgovornih aktivnosti (Lin-Hi i Muller, 2013.).

Usprkos tomu, studije koje konceptualiziraju područja društvene odgovornosti i istražuju razložnost, poimanje i autentičnost društveno odgovornog ponašanja, oslanjaju se na stajališta interesno-utjecajnih skupina kao što su potrošači, korporativni menadžeri i menadžeri ljudskih potencijala uglavnom velikih poduzeća (Öberseder, Schlegelmilch i Murphy, 2013.) dok zanemaruju vlasnike i zaposlenike malih i srednjih poduzeća. Ova situacija iznenađuje utoliko što su mala i srednja poduzeća dominantna u ukupnom broju svih poduzeća diljem svijeta.

Društvena odgovornost marketinga označava marketinško ponašanje koje nije orijentirano isključivo prema ostvarenju marketinških - tržišnih, prodajnih, profitnih ciljeva gospodarskih subjekata, već istovremeno teži zaštiti i jačanju interesu društva (Kotler i Keller, 2005.,str.22). Porter i Kramer (2006.) inzistiraju na koordiniranom povezivanju DOPa i aktivnosti takve prirode na razini različitih odjela jer alternativa sugerira da se radi o kozmetičkoj inicijativi odnosa s javnošću.

Povrh toga, široki i bogati fond znanja o društveno odgovornom ponašanju karakterizira heterogenost definicija i konceptualizacija (Lin-Hi i Muller, 2013.; Jamali i Mirshak, 2007.). Sveobuhvatna i široko prihvaćena konceptualizacija korporativne društvene odgovornosti i dalje ostaje aktualna tema (Öberseder, Schlegelmilch i Murphy, 2013.). Pozivajući se na teoriju interesno-utjecajnih skupina i na koncept autentičnosti, ovaj rad stoga integrira percepciju vlasnika malih i srednjih poduzeća u istraživanju područja društveno odgovornog marketinga u tranzicijskoj ekonomiji Hrvatske. Okruženje kao pretpostavka za ovu studiju je primjereno, budući da je većina studija društveno odgovornog ponašanja provedena u kontekstu razvijenih zemalja (Albareda i sur., 2007.; Antal i Sobczak, 2007.; Déniz i Suárez, 2005.; Juholin, 2004.; Midttun i sur., 2012.; Öberseder i sur., 2013.; Du, Bhattacharya i Sen, 2010.; Laczniak i Murphy, 2006.; Fukukawa i Teramotoa, 2009.). lako broj studija DOP-a u kontekstu zemalja u razvoju raste (Jamali i Mirshak, 2007.), malo toga je poznato o praksi DOP-a u tranzicijskim zemljama srednje i istočne Europe (Razum, 2015.; Pejić-Bach, Omazić i Zoroja, 2014.; Omazić i Banovac, 2012.; Elms, 2006.).

\subsection{Društveno odgovorno ponašanje u malim i srednjim poduzećima: definicija i primjena}

lako se na DOP tradicionalno gledalo kao na prostor namijenjen velikim poduzećima, sektor malog $\mathrm{i}$ srednjeg poduzetništva svijetu postaje sve značajniji u pogledu ekonomskog, društvenog i ekološkog utjecaja. Zbog toga, potrebno je skrenuti pozornost na raspravu i analizu načela i prakse u malim i srednjim poduzećima s ciljem da se ovaj sektor više ne nađe izvan prakse DOP (Spence, 1999.; Spence i sur., 2003., 2004.; Jenkins, 2004., 2009.; Murillo i Lozano, 2009.). Budući da mala i srednja poduzeća nisu samo umanjena verzija velikih poduzeća (Jenkins, 2004.) posebna se pozornost treba obratiti na specifične načine provođenja mjera društveno odgovornog marketinga, te kako se to razlikuje od prakse u velikim poduzećima i kako to objašnjava različita viđenja i ponašanja između njih u odnosu na održivi razvoj. S gledišta malih i srednjih poduzeća, važno je početi s načinom na koji je društveno odgovorno ponašanje definirano od strane istraživača i vlasnika/menadžera, pogotovo od kad se većina deklarira kako provodi društveno odgovorne aktivnosti (Saulquin i Schier, 2007.).

Prema rezultatima istraživanja provedenog na malim i srednjim poduzećima u Velikoj Britaniji, Jenkin (2009.) je istaknuo da je za poduzeća koja se smatraju oglednim primjerima u tom području, DOP prihvaćeno kao "sveobuhvatna“ ideja koja prožima temelje poslovanja. Vlasnici/menadžeri tih malih i srednjih poduzeća putem svojih poslovnih odluka očekuju pozitivan utjecaj na širok raspon dionika. Direktori malih i srednjih poduzeća ne vide DOP kao vanjski doprinos nego više kao sastavni dio načina na koji upravljaju svojim poduzećima. $\mathrm{Na}$ isti način, Blombäck i Wigren (2009.) smatraju kako se opredjeljenje poduzeća na DOP odnosi na
Brečić, R, Bradica, H., Anđelinović,M.

Primjena društveno odgovornog marketinga u poslovanju malih i srednjih poduzeća 
Brečić, R, Bradica, H., Anđelinović,M.

Primjena društveno odgovornog marketinga u poslovanju malih i srednjih poduzeća operativne aktivnosti, kao što je uvođenje mjera za očuvanju okoliša, a može obuhvatiti društvo uključivanjem u zajednicu i održavanjem dobrih radnih odnosa s lokalnim sudionicima (npr. lokalno sponzorstvo).

Drugo istraživanje je izabrano kako bi se usredotočili na mjere uvođenja DOP i pokušalo je klasificirati razinu i vrstu posvećenosti DOP od strane malih i srednjih poduzeća. Izolirane su tri glavne kategorije (Russo i Tencati, 2009.):

1. interne socijalne mjere kao što su razvoj talenta, provođenje zdravstvenih i socijalnih mjera i poboljšanje radnih uvjeta.

2. vanjske socijalne mjere kao što su razvoj mrežnih veza s lokalnim gospodarstvom, profesionalni razvoj i socijalna integracija

3. mjere za zaštitu okoliša kao što su smanjenje potrošnje energije, smanjivanje otpada i recikliranje otpada.

Na ovu temu, barometar održivog razvoja u sklopu francuskih malih i srednjih poduzeća (CROCIS, 2007. prema Kechiche i Soparnot, 2012.) izvještava da velika većina voditelja poduzeća tvrde da su provedene mjere održivog razvoja, navode kako upravljaju poduzećem imajući na umu mjere očuvanja okoliša ( $96 \%$ u području Pariza) i ukazuje da oko $47 \%$ malih i srednjih poduzeća ima dobre veze sa zajednicom kroz sponzorske dogovore, dobrotvorna događanja i poticaje za zapošljavanje. Čini se kako će lokalna zajednica biti važan dionik za većinu proučenih malih i srednjih poduzeća. Ista slika pojavljuje se i kod zaposlenika koji izgledaju kao skupina $s$ kojom se dobro ophode u većini malih i srednjih poduzeća (Hammann i sur., 2009.). Uočeni su mnogi primjeri mjera usmjerenih na razvoj talenta, poboljšanja uvjeta rada ili raznolikost na radnom mjestu u smislu dobne i spolne strukture (Kechiche i Soparnot, 2012.).

Ovi rezultati potvrđuju rezultate istraživanja Saulquina i Schiera (2010.), koji ispituju DOP u malim i srednjim poduzećima s gledišta različitih dionika. Izvještavaju kako mala i srednja poduzeća pokazuju veliku brigu za dobrobit svojih zaposlenika i svojih veza u zajednici. To je objašnjeno bliskošću između glavnih direktora i njihovog osoblja te činjenicom da mala i srednja poduzeća često imaju vrlo jake veze sa svojim neposrednim lokalitetom.
Širok izbor praksi i mjera DOP u malim i srednjim poduzećima obuhvaćenih u istraživačkom radu je osigurao put za buduća istraživanja o konkretnim čimbenicima koji mogu pomoći direktorima malih $\mathrm{i}$ srednjih poduzeća u integraciji i provođenju mjera DOP.

\subsection{Određivanje čimbenika koji utječu na društveno odgovorno ponašanje malih i srednjih poduzeća}

Mala i srednja poduzeća mogu se razlikovati u pogledu veličine, ciljeva, djelatnosti, pa tako i predanost DOP ovisi o različitim čimbenicima. Lepoutre i Heene (2006.) utvrdili su da karakteristike kao što su osobnost direktora poduzeća, organizacijski čimbenici i druge karakteristike utječu na način primjene i stila provođenja DOP u praksi. Slično tome, Labelle i Saint Pierre (2010.) identificirali su tri grupe čimbenika (institucionalni, organizacijski i ljudski) koji mogu utjecati na odluku o uvođenju politike odgovornosti. Ipak, određeni čimbenici i karakteristike kao što su veličina poduzeća, lokacija kao i osobni čimbenici (povezani s osobnošću direktora poslovanja malih i srednjih poduzeća) su češće identificirani u istraživanju od ostalih čimbenika.

Veličina poduzeća je organizacijski čimbenik u uvođenju i provedbi DOP malih i srednjih poduzeća (Labelle i Saint Pierre, 2010.). Neke studije ukazuju na postojanje pozitivne veze između veličine poduzeća i njegove predanosti DOP-u (Cabagnols i Le Bas, 2008.). Veća poduzeća su više osjetljiva na pitanja DOP od onih manjih ili mikro poduzeća posebno na području okoliša (Sharma, 2000.). Velika poduzeća su često u mogućnosti apsorbirati fiksne troškove i imaju bolji pristup resursima. Velika radna snaga može određene čimbenike učiniti privlačnijima (Kechiche i Soparnot, 2012.). Međutim, slučajevi u praksi su raznoliki i rezultati istraživanja se razlikuju po tom pitanju.

Drugi odlučujući čimbenik je uloga vlasnika/menadžera malog ili srednjeg poduzeća. Manji omjer poslovanja povećava osobni kontakt direktora i njegovog osoblja i stvara više neformalne radne odnose isto kao i manji jaz između strateških i operativnih centara poslovanja (Torrès, 2000.). Ista dinamika postoji i izvana između poduzeća i vanjskih dionika (Torrès, 2000.). To bi moglo značiti da u pravilu direktori malih i srednjih poduzeća imaju 
veću vjerojatnost da će razviti više etičko nego ekonomsko razmišljanje o DOP-u.

Prema istraživanju koje su proveli Kechiche i Soparnot (2012.), glavni pokretač provedbe politike DOP prema mišljenju 64,7\% vlasnika/menadžera malih i srednjih poduzeća, je građanstvo. Od svih motivacijskih čimbenika, osobni ili individualni razlozi ostaju najvažniji u francuskim malim i srednjim poduzećima čime se potvrđuju rezultati Courrenta (2004.), Hemingwaya (2005.) i Murilla te Lozana (2006.).

Prema mišljenju nekih autora (Spence i sur., 2007a.; Spence i sur., 2007b.) javno oduševljenje građanstva je odraz osobnih vrijednosti i uvjerenja menadžera poduzeća. Zapravo, prema Gondu i Igalensu (2008.) „DOP u malim i srednjim poduzećima uvelike ovisi o osobnosti i osobnim uvjerenjima njihovih glavnih direktora“. Slično tome, Spence i autori (2007a.)istaknuli su činjenicu da su direktorova vizija budućnosti poslovanja i njegovo razumijevanje i percepcija internih resursa ti koji imaju utjecaj na posvećenost DOP-u. Direktori malih i srednjih poduzeća ne podliježu pritisku dioničara koji očekuju kratkoročne povrate i to im omogućava da ulažu u područje ljudske dinamike i stvaranje odnosa sa svim zainteresiranim dionicima, imajući na umu da stvaranje profita nije jedini svrha društva. Naslanjajući se na to, znanstvenici su istraživali i pokušali objasniti ključne komponente direktorskih etičkih sustava vrijednosti. Ede i autori (2000.) ukazuju na to da godine igraju odlučujuću ulogu u sustavu vrijednosti jednog direktora malog ili srednjeg poduzeća zaključujući da su mlađi direktori više društveno odgovorni od onih starije dobi. Isto tako, oni vjeruju da niti spol niti obrazovanje nemaju tako značajnu ulogu kada je u pitanju ljestvica vrijednosti direktora. Međutim, drugi znanstvenici i smatraju kako direktorov stupanj obrazovanja igra značajnu ulogu u toj domeni (Spence i Lozano, 2000.).

Ostali autori smatraju kako bi teritorijalna kohezija i lokalno sjedište poduzeća moglo imati utjecaj na inicijativu provedbe DOP-a (Kechiche i Soparnot, 2012.). Većina malih i srednjih poduzeća ima jaka lokalna uporišta i identificiraju se s regijom u kojoj su utemeljene. Osim toga, lokalno područje nudi malim poduzećima brojne koristi i resurse kao što su infrastruktura, radna snaga, sirovine, te u zamjenu očekuje neke ekonomske koristi i koristi za zajednicu. Stoga vlasnik/menadžer malog ili srednjeg poduzeća mora biti siguran da su njegovi postupci u skladu s vrijednostima i očekivanjima lokalne zajednice.

Prema Torrèsu (2003:125), iz vanjskog gledišta, slika poduzeća će biti pod utjecajem ljudskog kapitala kojeg direktor može zaposliti i to često igra ključnu ulogu u njegovom javnom, profesionalnom, socijalnom i političkom poslovanju“. Ti odnosi koji povezuju malo ili srednje poduzeće s različitim vanjskim dionicima su posebno važni za poticanje i provedbu mjera i prakse DOP-a i mogu također utjecati na ponašanje ostalih malih i srednjih poduzeća u istom sektoru. U tom smislu, cilj je zajedno se suočiti s ekološkim i socijalnim pitanjima, smanjiti troškove provedbe i izaći izvan ograničenja nametnutih od strane nekih vrsta tržišta.

Nadalje nakon ovog obrazloženja, neki autori smatraju kako je opredjeljenje za DOP u malim i srednjim poduzećima pod pritiskom vlasnika poduzeća (Worthington i sur., 2008.). Lepoutre i Heene (2006.) smatraju kako su mala i srednja poduzeća više osjetlijiva na praksu internih dionika npr. njihovih zaposlenika, klijenata i dobavljača. Zapravo, prema mišljenju nekih autora, to su tri najutjecajnija dionika za mala i srednja poduzeća (Gadenne i sur. 2009.). Ova hipoteza nosi još veću težinu kada se uzme u obzir da mnoga mala i srednja poduzeća rade zajedno s velikim poduzećima i potiču razvijanje i promjenu metoda proizvodnje, te istovremeno nastoje očuvati okoliš i jamčiti ravnopravne društvene poslove. Kechiche i Soparnot (2012.) smatraju da zbog lanca vrijednosti postoji pritisak velikih poduzeća koje potiču mala i srednja poduzeća na primjenu DOP.

Nastavljajući dalje ovu raspravu, drugi pravci istraživanja zaključuju da u slučaju malih i srednjih poduzeća, pritisak od strane dionika nije učinkovit i nije katalizator u provođenju mjera koje izlaze iz okvira legalnih i administrativnih zahtjeva (Ellerup Nielsen i Thomsen, 2009.). Prema istim autorima, mala i srednja poduzeća nisu oduševljena kolektivnim pitanjima. Quairel i Auberger (2007.) smatraju da francuska mala i srednja poduzeća u pogledu uvođenja politika DOP-a nisu pod utjecajem velikih poduzeća.

\subsection{Posljedice primjene društveno odgovor- nog ponašanja na poslovanje malih i srednjih poduzeća}

Prema nekoliko istraživanja, provedba društveno odgovornog marketinga donosi određeni broj prednosti za poduzeće - kao na primjer poboljšanje
Brečić, R, Bradica, H., Anđelinović,M.

Primjena društveno odgovornog marketinga u poslovanju malih i srednjih poduzeća 
Brečić, R, Bradica, H., Anđelinović,M.

Primjena društveno odgovornog marketinga u poslovanju malih i srednjih poduzeća ugleda i imidža poduzeća, poboljšanje radnih odnosa s osobljem, poboljšanje u proizvodnim procesima i kvaliteti (Vives, 2006.; Saulquin i Schier, 2007.; Worthington i sur., 2008.; Russo i Tencati, 2009.).

Prema Jenkinsu (2009.), donošenjem strategije društveno odgovornog marketinga, mala i srednja poduzeća mogu razviti inovativne proizvode i usluge i na taj način se pokušati izaći na nova tržišta. Nekoliko studija ističe činjenicu da odgovorno ponašanje donosi financijske prednosti kao što su smanjenje troškova i povećanje učinkovitosti (Jenkins, 2009.; Russo i Tencati, 2009.). Zapravo, uvođenjem pažljivije prakse i mjera upravljanja ili korištenjem supstituta proizvoda koji su manje štetni za svijet, mala i srednja poduzeća mogu smanjiti rasipanje i osigurati smanjenje troškova ili izdataka (Reynaud i Mathieu, 2005.).

Društveno odgovoran marketing može biti katalizator za povećanje motivacije i produktivnosti među radnom snagom poduzeća (Saulquin i Schier, 2007.). Istovremeno, svijest i razumijevanje izazova i problema uključenih u društveno odgovoran marketing mogu činiti vrlo dobru bazu za konkurentsku diferencijaciju i doprinijeti poboljšanju imidža poduzeća. DOP se može promatrati kao metoda za postizanje ciljeva poduzeća i to može imati vrlo korisne učinke u komunikaciji s dionicima poduzeća - posebno s klijentima poduzeća i poslovnim partnerima - a posljedica toga će biti pojačana slika i ugled poduzeća (Collins i sur., 2007.).

Dakako, ne slažu se sva istraživanja s prethodno navedenim. Druga struja istraživanja smatra da mala i srednja poduzeća imaju tendenciju da se obvežu na društvenu odgovornost zbog vlastite koristi i ne koriste ju kao metodu oglašavanja ili dio odnosa $s$ javnošću kao što je slučaj u velikim poduzećima (Jenkins, 2006.). Zapravo, prilično neformalna strategija koja karakterizira mala i srednja poduzeća podrazumijeva da DOP ima više intuitivnu nego stratešku tendenciju (Fassin, 2008.) i da se unutar komunikacijskog okvira vlasnika/menadžera koristi rijetko samo kao strateški dokument u svom posjedu.

\subsection{Utjecaj vlasnika/menadžera na društvenu odgovornost marketinga malih i srednjih poduzeća}

lako mala i srednja poduzeća sve više i više integ- riraju društveno odgovorno ponašanje u svoje svakodnevno poslovanje, moraju svladati mnoge prepreke. Nekoliko istraživanja ispitalo je ograničenja za uspješnu provedbu održivog razvoja za mala i srednja poduzeća u širokom rasponu poslovnih situacija (Lapointe i Gendron, 2006.). Dok se priznaje povećanje razine svijesti o društveno odgovornom marketingu, istraživanja ukazuju na to kako su neki vlasnici/menadžeri i dalje skeptični u pogledu pogodnosti koje mogu proizaći iz društveno odgovornog marketinga i nisu skloni izaći izvan zadanih pravnih okvira (Revell i Blackburn, 2007.). Zapravo, ovi vlasnici/menadžeri navode kako su previše opterećeni svakodnevnim poslovnim aktivnostima koje nalaže poslovanje i kako su previše zauzeti da bi se bavili pitanjima koja se odnose na društvo u cjelini i koja nemaju izravan povrat ili korist (Lepoutre i Heene, 2006.). Oni također smatraju kako postoji nedostatak informacija o društveno odgovornom marketingu i da in to ne potiče da postanu predani takvom ponašanju.

U skladu s tim, barometar održivog razvoja također ističe činjenicu kako je nedostatak informacija prva prepreka uvođenju odgovornog upravljanja za vlasnike/menadžere malih i srednjih poduzeća (47\% u 2007.), unatoč brojnim inicijativama i kampanjama za povećanje svijesti i pomoći direktorima u prevladavanju ove prepreke (AFCl, 2006.).

Osim toga, mala i srednja poduzeća obično nemaju kapacitet za samostalno prikupljanje i analizu korisnih podataka na temu održivog razvoja (Lepoutre i Heene, 2006.). Uz to, njihov pristup informacijama je ograničen isto kao i njihovo znanje o društveno odgovornom marketingu. Istraživanje na 138 vlasnika/menadžera malih i srednjih poduzeća koje je proveo Berger - Douce (2008.) (prema Kechiche i Soparnot, 2012.) pokazuje kako manje od 30\% njih zna nešto o podršci organizacija koje nude pomoć u uvođenju odgovornog ponašanja u poslovanje i manje od $25 \%$ zna nešto o referentnim podacima društveno odgovornog ponašanja. Ova praznina ilustrira reaktivni nasuprot proaktivnom pristupu u odnosu na proces traženja informacija.

Daljnja prepreka je trošak uvođenja razumnih mjera i nedostatak financijskih sredstava (Berger-Douce, 2008.; Revell i Blackburn, 2007.). Ključna stvar je percepcija vlasnika/menadžera o potrebnim sredstvima za društveno odgovoran marketing (Spence 
L. i sur., 2007.). Vlasnici/menadžeri malih i srednjih poduzeća koji vjeruju da njihova poduzeća nemaju dovoljno financijskih sredstava imaju manju vjerojatnost pozitivnog mišljenja o društveno odgovornom marketingu i vjeruju da se sredstva potrebna za investicije neće nadoknaditi u smislu uštede. Predanost vlasnika/menadžera malih i srednjih poduzeća susreće se i s preprekama na tržištu, uglavnom s poteškoćama ekološke primjene i/ili socijalnih zakona zbog njihove kompleksnosti i rigidnosti određenih postupaka. Oni često osjećaju nedostatak adekvatnih usluga podrške i infrastrukture.

Nedostatak dostupnosti alata društveno odgovornog marketinga je također kriv za nedostatak primjene. Oni koji postoje čini se da su dizajnirani za velika poduzeća i nisu lako prilagodljiva malim i srednjim poduzećima. Prema tome formalni sustavi upravljanja okolišem nisu bili vrlo uspješni među malim i srednjim poduzećima jer njihova kompleksnost onemogućava adaptaciju u manjim poduzećima (Berger-Douce, 2010.).

Unatoč preprekama s kojima su suočena mala i srednja poduzeća, ideja o provođenju mjera društveno odgovornog marketinga i dalje nastoji zaživjeti među vlasnicima/menadžerima malih i srednjih poduzeća koji su svjesni mnogih prednosti odgovornog upravljanja.

\section{Metodologija}

S obzirom na nedostatak istraživanja percepcije o društveno odgovornom marketingu u malim i srednjim poduzećima, kao i ograničenost empirijske literature, primijenjeno je kvalitativno istraživanje. Ovaj pristup smatra se primjerenim pri razumijevanju i otkrivanju kompleksnosti uključenih u percepciju društvene odgovornosti poduzeća (Oberseder, Schlegelmich i Murphy, 2013.). I doista, smatra se da je kvalitativni pristup primjeren proučavanju neistraženih i kompleksnih pitanja temeljenih na percepciji, vjerovanjima i vrijednostima ispitanika (Birkinshaw i sur., 2011.). Prema tome, primijenjen je pristup temeljen na bazičnoj teoriji, imajući u vidu činjenicu da je cilj rada identificirati dimenzije društveno odgovornog marketinga (DOM-a) malih i srednjih poduzeća (MSP-a), analizirati stupanj razvoja DOM-a u MSP-a, te utvrditi čimbenike koji utječu na primjenu DOM-a u MSP-a. Preciznije, sveobuhvatni intervjui, analiza bilješki s terena, internetskih stranica poduzeća te izvješća vezanih uz DOM pokazali su se primjerenima za ovo istraživanje.

U svrhu boljeg razumijevanja percepcije DOM-a, fokus je stavljen na vlasnike/menadžere malih $\mathrm{i}$ srednjih poduzeća $s$ različitim stupnjevima angažiranosti i opredijeljenosti za DOM, kao i raznolike strategije društveno odgovornog marketinga (Creswell, 2007.). Takav je pristup usvojen ne bi li se smanjila moguća pristranost, a osigurali različiti odgovori. Pojedinci su, kao izvor informacija, identificirani višestrukim metodama, uključujući izravan pristup, umrežavanje te tzv. efekt snježne grude (eng. snowballing approach). Te su metode naime identificirane kao naročito učinkovite u tranzicijskim gospodarstvima i institucionalnim okruženjima (Birkinshaw i sur., 2011.).

Ispitanici (16 vlasnika/menadžera malih i srednjih poduzeća) predstavljaju presjek različitih gospodarskih grana, uključujući izdavača knjiga, prodaju automobila, servisnu djelatnost, promet, proizvodnju hrane, maloprodaju, proizvodnju i prodaju ekološke hrane, igre na sreću, proizvođača sanitarne opreme, distribuciju medicinske opreme, prodaju robe široke potrošnje, marketinšku agenciju, građevinske tvrtke, te opskrbljivača sanitarnim armaturama (Tablica 2.u nastavku). Studijski kontekst Hrvatske je primjeren jer je ovo tranzicijsko gospodarstvo imalo političku i gospodarsku povijest punu izazova i jer je 2013. Hrvatska postala državom članicom EU. Ekonomski razvoj Hrvatske, kao i njeno političko i društveno okruženje razlikuju se stoga u priličnoj mjeri od njezinih europskih pandana. Inicijative vezane uz društveno odgovorno ponašanje, diskusije i implementacija programa u ovom su kontekstu također jedinstveni i još uvijek nedovoljno istraženi.

Dostupnost menadžera dogovarana je s vlasnicima poduzeća, pri čemu im je zajamčena povjerljivost kako bi se potakli otvoreni i detaljni odgovori ispitanika kao i pristup drugim podacima. Ukupno je provedeno 16 sveobuhvatnih i temeljitih intervjua s vlasnicima/menadžerima u periodu od šest mjeseci krajem 2015. i početkom 2016. Protokol intervjua razvijen je na temelju rada Öberseder i Murphy (2013.). Smjernice intervjua su probno testirane (McCracken, 1988.), a menadžerima je zajamčena anonimnost. Presudan čimbenik za uspjeh intervjua bila je garancija da će se poštivati tajnost
Brečić, R, Bradica, H., Anđelinović,M.

Primjena društveno odgovornog marketinga u poslovanju malih i srednjih poduzeća 
Brečić, R, Bradica, H., Anđelinović,M.

Primjena društveno odgovornog marketinga u poslovanju malih $\mathrm{i}$ srednjih poduzeća

Tablica 1. Opis uzorka

\begin{tabular}{|c|c|c|c|c|}
\hline Intervju & Djelatnost & $\begin{array}{l}\text { Dio poduzeća } \\
\text { odgovoran za DOP }\end{array}$ & $\begin{array}{c}\text { Trajanje intervjua } \\
\text { (minute) }\end{array}$ & Broj transkriptiranih stranica \\
\hline 1 & Izdavač knjiga & Marketing & 40 & 8 \\
\hline 2 & Prodaja automobila & Vlasnica & 35 & 7 \\
\hline 3 & Servisna djelatnost & Vlasnik & 30 & 6 \\
\hline 4 & Promet & Svi odjeli & 90 & 17 \\
\hline 5 & Proizvodnja hrane & Svi odjeli & 55 & 14 \\
\hline 6 & Maloprodaja & Marketing & 68 & 18 \\
\hline 7 & Proizvodnja hrane & Marketing & 40 & 10 \\
\hline 8 & Igre na sreću & Marketing & 55 & 10 \\
\hline 9 & $\begin{array}{c}\text { Proizvodnja i prodaja ekološke } \\
\text { hrane }\end{array}$ & Svi odjeli & 36 & 9 \\
\hline 10 & Proizvođač sanitarne opreme & Svi odjeli & 52 & 16 \\
\hline 11 & Distribucija medicinske opreme & Svi odjeli & 32 & 8 \\
\hline 12 & Prodaja robe široke potrošnje & Marketing & 60 & 11 \\
\hline 13 & Prodaja lijekova & Svi odjeli & 62 & 12 \\
\hline 14 & Prodaja osiguranja & Marketing & 30 & 6 \\
\hline 15 & Marketinška agencija & Svi odjeli & 30 & 7 \\
\hline 16 & Građevina & Svi odjeli & 60 & 12 \\
\hline
\end{tabular}

Izvor: izrada autora.

u odnosu na individualne sudionike kao i poduzeća koje predstavljaju (Fukukawa i Teramoto, 2009.).

Svrha intervjua bila je identificirati dimenzije DOM-a MSP-a; analizirati stupanj razvoja DOM-a te utvrditi čimbenike koji utječu na primjenu DOM-a u MSP-a u kontekstu tranzicijske ekonomije. Pitanja postavljena tijekom intervjua bazirana su na četiri glavne teme: definicije i djelokrug aktivnosti DOM-a: odgovornost - za koga i za što, percepcija DOM-a od strane zaposlenika i činjenice o poduzeću. Trajanje intervjua bilo je između četrdeset minuta i dva sata. Na početku intervjua vlasnici/menadžeri su uglavnom oduševljeno pričali o DOM-u u smislu "gle' kako smo sjajni", ali kako je vrijeme odmicalo i intervju postajao opušteniji,vlasnici/menadžeri su davali iskrenije odgovore i bili kritičniji glede društveno odgovornog ponašanja svog poduzeća. Svi su intervjui snimljeni, a za kvalitetnu analizu su napravljeni transkripti.

\section{Rezultati istraživanja}

Pri analizi podataka primijenjeni su pristupi koje su skicirali Miles i Huberman (1984.). Snimljeni intervjui transkriptiranisu doslovno, a u slučajevima gdje su ispitanici bili protiv snimanja, napravljeni su terenski zapisi i bilješke. U takovim uvjetima primijenjeno je "pravilo 24 sata" da bi se osigurala točnost i kronologija događaja (Gioia i Thomas, 1996.). Izabrano je "pravilo 24 sata" i zato da bi se "kapitalizirala neposrednost podataka" (Gioia i Thomas, 1996:374). Autor rada se pobrinuo da se terenske bilješke transkriptiraju te da se izradi kronologija događaja odmah nakon svakog intervjua. U slučajevima gdje su zapisivane terenske bilješke, one su se provjeravale kod ispitanika kako bi se osigurala jasnoća i točnost prikaza njihovih stavova. To je poslužilo kao baza analize.

Podaci su analizirani koristeći tehniku tematske analize, gdje se proučavaju transkripti kako bi se identificirali obrasci značenja i pojavnost tema (Boyatzis, 1998.).Analiza podataka je stoga započela detaljnim šifriranjem transkripata, a taj je proces iznjedrio niz kategorija.Analizirane su kategorizacije transkripata te su identificirane opće teme koje su koncentrirane oko tri područja: (1) dimenzije DOM-a MSP-a, (2) stupanj razvoja DOM-a u MSP-a te (3) čimbenici koji utječu na primjenu DOM-a u MSP-a.

\subsection{Dimenzije društveno odgovornog marke- tinga malih i srednjih poduzeća}

Prvo istraživačko pitanje odnosilo se na ispitivanje percepcije menadžera/vlasnika MSP-a o njihovom poimanju društveno odgovornog marketinga. Pri tome je uočeno kako je većina menadžera/vlasnika upoznata s pojmom društveno odgovornog marketinga i dimenzijama koje bi takvo ponašanje trebalo obuhvaćati. Gotovo svi ispitanici su istak- 
nuli kako se društveno-odgovoran marketing treba usmjeravati prema primarnim interesno-utjecajnim skupinama.

„DOM dijelim u dvije osnovne grupe: ponašanje prema zaposlenicima i ponašanje prema okolini (potrošači, dobavljači, društvo, zaštita okoliša). Mislim da smo prema okolini vrlo angažirani" (maloprodaja).

„Vodimo brigu 0 zaštiti okoliša, vodimo brigu 0 zaposlenicima i o njihovom zadovoljstvu i o napretku radom u našoj firmi. Provodimo različite PR i promotivne kampanje poticanja čitanja kako kod mladih tako i kod odraslih, surađujemo s kulturnim i obrazovnim institucijama, potičemo nacionalne projekte, surađujemo s vladinim institucijama na istim tim nacionalnim projektima i ulažemo znači u podizanje svijesti o potrebi obrazovanja i čitanja od najranijeg, najranije dobi“ (izdavač knjiga).

„DOM aktivnosti su najviše usmjerene na zaposlenike i potrošače. Radimo sve što je u svijetu poznato, nešto i izvan zakonskih propisa. Po meni bi trebalo tu malo više poraditi, jer je nedopustivo da se filantropskim djelovanjem glorificira poduzeće koje istovremeno svojim aktivnostima potencira stvaranje velikih teškoća u financijama pojedinca ili čak zdravstvene probleme. Ono što je po meni najviše zapostavljeno je svjesnost organizacije o svakome svome proizvodu ili usluzi koju nudi. Naime, možete vi školovati, stipendirati ili pomagati ne znam koliko djece, ali ako vaš proizvod može počiniti štete društvu i pojedincu koji ga konzumira, onda je po meni primarni zadatak poduzeća da pokuša umanjiti moguće štetne posljedice svoje usluge ili proizvoda i učini je manje štetnom koliko je god to moguće... Dakle, primarni cilj naše djelatnosti bi trebao biti taj da preventivno djelujemo na smanjenje mogućih štetnih posljedica koje naši proizvodi ili usluge mogu učiniti društvu“ (igre na sreću).

„DOM u našem poduzeću u stvari zrcali samo ono što u osnovi pokušavamo napraviti: imati kvalitetan odnos prema djelatnicima, kupcima, partnerima (dobavljačima) te transparentno poslovati pri tome čuvati zdravlje ljudi i okoliša. Aktivnosti koje spadaju u naše odgovorno ponašanje su Edukacija (djelatnika, kupaca, partnera), standardi poslovanja (unaprjeđenje i/ili uvođenje) koji poboljšavaju efikasnost, zadovoljstvo i energetsku učinkovitost, recikliranje, okretanje ka obnovljivim izvorima energije i ekološkoj poljoprivredi." (proizvodnja i prodaja ekološke hrane).

"danas ljudi imaju pristup mnoštvu informacija, kupca ne možete više obmanuti ili zavarati...on može birati između mnoštva proizvoda pa se i mi moramo boriti da izaberu baš naš proizvod. Tu nam pomaže DOM,'(proizvođač sanitarne opreme).

„DOM danas nije luksuz već nužnost poslovanja. Vraćanje dijela profita u zajednicu u kojoj poslujemo nužno je u ostvarivanju konkurentnosti i ispunjenju očekivanja svih zaposlenika. Najvažnije interesne skupine su nam potrošači i zaposlenici, potom dioničari i dobavljači“ (distributer medicinske opreme).

„Nama je jako bitno da se shvati da DOM radimo radi svih ljudi oko nas, bitno nam je da potrošači to prepoznaju.Znači da nisi orijentiran isključivo na profit, ad djeluješ pozitivno na potrošače, zajednicu, okoliš, da se ne bogatiš nauštrb drugih." (prodaja robe široke potrošnje).

„Odgovorno se ponašamo ne samo prema vani, nego i unutar poduzeća. Vodimo brigu o zaposlenicima, kupcima, zajednici u kojoj živimo, zaštiti okoliša, partnerima... dajemo sliku kako treba raditi s ljudima. Naš glavni motiv je pomoći, unaprijediti, poduprijeti - neovisno o tome moramo li ili želimo li."(prodaja osiguranja).

„DOM je trostruka odgovornost - prema zajednici u kojoj radimo, prema korisnicima usluga i prema dioničarima. Odgovornost je društvena, financijska i socijalna... mislim da je provođenje aktivnosti DOM-a jedina mogućnost dugoročnog poslovanja“ (prodaja lijekova).

„...budući da se mi bavimo medijima mi smo ograničeni samo na promociju društveno odgovornog marketinga... pružamo kvalitetan program, promoviramo društveno pozitivne vrijednosti, pratimo rad lokalne zajednice i rad Vlade." (marketinška agencija).

„DOM je strateško upravljanje poslovnim prilikama i rizicima u okruženju poduzeća, s ciljem ostvarenja konkurentnog poslovnog modela... ili jednostavnije rečeno... sredstvo koje osigurava dozvolu za rad" (građevinsko poduzeće).

$\mathrm{Na}$ temelju navedenih odgovora, zaključak je kako su vlasnici/menadžeri malih i srednjih poduzeća u velikoj mjeri upoznati s pojmom društveno odgov-
Brečić, R, Bradica, H., Anđelinović,M.

Primjena društveno odgovornog marketinga u poslovanju malih i srednjih poduzeća 
Brečić, R, Bradica, H., Anđelinović,M.

Primjena društveno odgovornog marketinga u poslovanju malih $\mathrm{i}$ srednjih poduzeća ornog marketinga i dimenzijama koje bi takvo ponašanje trebalo obuhvaćati. Pri tome se uočavaju razlike između pojedinih poduzeća. Dok su mala poduzeća skromnim aktivnostima DOM-a više okrenuta potrošačima i zaposlenicima, kod srednje velikih poduzeća primjećuje se više aktivnosti i uključivanje više interesno-utjecajnih skupina (dobavljači, okolišs, zajednica u kojoj žive).

\subsection{Društveno odgovoran marketing usmjeren prema potrošačima}

Drugo istraživačko pitanje imalo je za cilj ispitati konkretne aktivnosti društveno odgovornog marketinga malih i srednjih poduzeća usmjeren prema potrošačima.Pri tome se ističu aktivnosti kao što su: ponuda vrhunskih i kvalitetnih proizvoda, ponuda širokog asortimana proizvoda, zaštita potrošača od štetnih proizvoda, uvođenje sustava kvalitete proizvoda, informiranost potrošača, snižavanje cijena, edukacije potrošača.

„Što se tiče potrošača znači nudimo proizvode vrhunske kvalitete o kojima in informiramo kroz različite načine promocije i oglašavanja, s time da se strogo vodi briga o okolišu kroz reciklirane materijale proizvoda,odnosno papir,nudimo i dodatnu vrijednost itd." (izdavač knjiga).

„Zabranjene su bilo kakve malverzacije, obmanjivanje kupaca ili obmanjivanje društva i zakona koje pred nas stavlja država.... kod nas bilo kakva pritužba kupca nije obična floskula, vrlo ozbiljno i oprezno se bavimo time... Naš motiv je prodavati zdravstveno ispravnu robu, ali naravno i bilježiti profit... Modificirali smo ponašanje.... Spustili smo cijene do maksimuma, uveli smo sve moguće akcije poticanja kupnje, ostaje nam još poboljšati usluge..." (maloprodaja).

„..višse se vodi računa o profitu nego o kvaliteti ili izvorima nabave... na papiru se deklarira kao da pratimo sve trendove, ali u zbilji priča ne odgovara tome..." (maloprodaja).

„Potrošačima dajemo sve informacije da mogu donijeti odgovarajuću odluku o igri, nudimo im informacije o potencijalnoj ovisnosti, besplatne telefone za razgovor s doktorima... Kada im se spomene ime našeg poduzeća, potrošači najviše pitaju može li im se srediti dobitak na lotu. Morali smo jako puno raditi na razuvjeravanju od tih neistina." (igre na sreću).
„Mi ih volimo nazivati osviješteni kupci, bez njih nema niti nas. Kupac je za nas svetinja i stalno je u centru našeg promišljanja. Što mu treba, kako će reagirati, kako da mu olakšamo neke stvari, informiramo ga, motiviramo, kako da osjeti brižnost, kako da raste s nama itd. Da, naši kupci su jako zahtjevni. Sve gledaju i komentiraju: od toga kakve vrećice imamo, što radimo sa smećem, recikliramo li, kako deklariramo proizvode, kakvi su nam zaposlenici, vrlo jasno žele komunicirati jer imaju povjerenje u ono što radimo i ne „dopuštaju“ nam da „skrenemo“ s puta, tjeraju nad da budemo bolji.Ali sve to ima pozitivan utjecaj na naš imidž... pa mi smo zahvaljujući tome izrasli..." (proizvođač i distributer ekološke hrane).

„Za potrošače aktivnosti DOM-a deklarativno imaju važnu ulogu u kupovini, ali kada vade novčanik tada cijena odlučuje." (građevinsko poduzeće).

Iz svega navedenog, zaključak kako su mala i srednja poduzeća ulažu popriličan napor u razvoj društveno odgovornog marketinga prema potrošačima. Pri tome vlasnici/menadžeri ističu da je problem kod takvih aktivnosti što ih potrošači nedovoljno cijene i što konačnu odluku o kupovini ne donose na temelju aktivnosti DOM-a, nego uglavnom na temelju cijene proizvoda. A s druge strane, cijena proizvoda koji slijedi načela društveno odgovornog marketinga, u većini slučajeva je iznad cijene proizvoda koji ne uključuje takve aktivnosti (npr. ekološki prehrambeni proizvodi su u prosjeku 30\% skuplji od konvencionalnih prehrambenih proizvoda).

\subsection{Društveno odgovoran marketing usmje- ren prema zaposlenicima}

Jedno od istraživačkih pitanja odnosilo se na aktivnosti DOM-a koje vlasnici/menadžeri malih i srednjih poduzeća poduzimaju u odnosu na zaposlenike.Pri tome se zapaža kako su zaposlenici važna interesno-utjecajna skupina, a najznačajnije aktivnosti su: edukacije i osposobljavanje; pružanje prilika za napredovanje; sigurnost radnog mjesta; interna komunikacija; evaluacija zadovoljstva zaposlenika; zdravstveno osiguranje, osiguranje dobrih radnih uvjeta; nagrade za dobro obavljen posao.

„Odnos prema zaposlenicima, u našem poduzeću najvećim dijelom se odnosi na poticanje stimulativnog i uređenog okruženja, neprestanim poboljšanjem radnih uvjeta, poticanjem na određivanje 
zajedničkih ciljeva težimo, ugodnijoj i opuštenijoj atmosferi koja motivacijski utječe na naše zaposlenike." (izdavač knjiga).

„Zaposlenici su naš najdragocjeniji kapital, educiramo ih, potičemo da osobno rastu, napreduju (pa ako to znači i odlazak iz našeg sustava pomažemo mu da se bolje snađe uz preporuke i sl.), istražujemo njihova zadovoljstva i nezadovoljstva, slušamo i učimo ali i zahtjevno tražimo napredovanje i posvećenost zajedničkoj misiji..." (proizvodnja i prodaja ekološke hrane).

„Puno radimo sa zaposlenicima. Pokrećemo projekte za mlade ljude da upoznaju sve odjele. Ispunjavamo sve obveze na vrijeme... Zaista im pružamo puno mogućnosti." (prodaja robe široke potrošnje).

„Zaposlenike smo uključili u volontiranje, tko god se odazvao imao je Slobodan dan. Čistili smo pet gradova na različitim lokacijama, jezera, rijeke.. Bitno je da su zaposlenici zadovoljni,pružamo dosta mogućnosti za edukaciju, sistematske preglede. Mi ne bi imali ovako dobru prodaju da nemamo tako dobro prodajno osoblje. Možemo mi čuda napraviti u upravi i u marketingu, ali ako naš djelatnik na blagajni ne zna to iskomunicirati, onda nismo ništa napravili. Prodavači su fantastični jer znaju uvjeriti da je pamučna torba bolja od plastične..." (prodaja lijekova).

„Imamo dobre financijske stimulacije, ali i niz drugih aktivnosti. npr. kreativne centre, obiteljski dan, dan svih naših zaposlenika i njihovih obitelji. Na taj se dan svi okupimo i družimo. Želimo svi biti jedna velika zajednica. Tu ne moraju zaposlenici doći ako ne žele, ali kada vidiš da ih se odazvalo više od $90 \%$ znaš da si na dobrom putu. To ti daje elan da ideš naprijed.... (distribucija medicinske opreme).

$\mathrm{Na}$ temelju navedenih izjava, može se zaključiti kako većina malih i srednjih poduzeća ima dobe odnose sa svojim zaposlenicima i da se vlasnicima/ menadžerima ova interesna skupina čini izrazito važnom. lako nisu u većini, dio ispitanih vlasnika/ menadžera MSP-a usmjerava društveno odgovorno marketinške aktivnosti.

\subsection{Stupanj razvoja društveno odgovornog marketinga u malim i srednjim poduzećima}

Stupanj razvoja društveno odgovornog marketinga u malim i srednjim poduzećima analiziran je prema podjeli Oberseder, Schlegelmich i Murphya (2013.). Autori navode da se poduzeća razlikuju ovisno o tome primjenjuju li društveno odgovoran marketing kao minimalan odgovor poduzeća, kao odgovor posebnog tima unutar poduzeća ili su takve aktivnosti temelj poslovanja poduzeća.

\subsection{Društveno odgovoran marketing kao minimalan odgovor poduzeća}

Polovina ispitanika obuhvaćena ovim istraživanjem iskreno odgovara kako primjenjuje nedovoljno aktivnosti koje se odnose na društveno odgovoran marketing. U najvećoj mjeri provode aktivnosti koje

Tablica 2. Percepcija vlasnika/menadžera MSP-a o dimenzijama društveno odgovornog marketinga

\begin{tabular}{|c|c|c|c|}
\hline & Djelatnost MSP-a & Veličina poduzeća & Dimenzija DOM-a \\
\hline 1 & Izdavač knjiga & Mala & Potrošači \\
\hline 2 & Prodaja automobila & Mala & Potrošači \\
\hline 3 & Servisna djelatnost & Mala & Zaposlenici \\
\hline 4 & Promet & Srednja & Zaposlenici, potrošači i lokalna zajednica \\
\hline 5 & Proizvodnja hrane & Srednja & Zaposlenici,potrošač i dobavljači \\
\hline 6 & Maloprodaja & Mala & Potrošači, lokalna zajednica \\
\hline 7 & Proizvodnja hrane & Srednja & Potrošači, zaposlenici i okoliš \\
\hline 8 & Igre na sreću & Srednja & Potrošači \\
\hline 9 & Proizvodnja i prodaja ekološke hrane & Srednja & Potrošači, zaposlenici, dobavljači \\
\hline 10 & Distributer sanitarne opreme & Srednja & Zaštita okoliša \\
\hline 11 & Distributer medicinske opreme & Srednja & Potrošači i zaposlenici \\
\hline 12 & Prodaja robe široke potrošnje & Srednja & Potrošači i zaposlenici \\
\hline 13 & Prodaja lijekova & Mala & Zaposlenici i potrošači \\
\hline 14 & Prodaja osiguranja & Mala & Zaposlenici i društvo \\
\hline 15 & Marketinška agencija & Mala & Društvo \\
\hline 16 & Građevina & Mala & Zaposlenici i potrošači \\
\hline
\end{tabular}

Izvor: izrada autora. 
Brečić, R, Bradica, H., Anđelinović,M.

Primjena društveno odgovornog marketinga u poslovanju malih $\mathrm{i}$ srednjih poduzeća

Tablica 3. Dimenzije i aktivnosti društveno odgovornog marketinga MSP-a

\begin{tabular}{|c|c|c|}
\hline \multicolumn{3}{|c|}{ Dimenzije i aktivnosti društveno odgovornog marketinga MSP-a } \\
\hline Dimenzija DOM-a & $\begin{array}{l}\text { Važnost za vlasni- } \\
\text { ka/menadžera }\end{array}$ & Aktivnosti društveno odgovornog marketinga \\
\hline Potrošači & Visoka & $\begin{array}{l}\text { Informiranje potrošača; ponuda širokog asortimana proizvoda; prodaja ispravnih } \\
\text { proizvoda; snižavanje cijena; česte prodajne akcije; isporuka kvalitetnih proizvoda; } \\
\text { zadržavanje lojalnosti: pružanje informacija o upotrebi proizvoda; }\end{array}$ \\
\hline Zaposlenici & Visoka & Jasna komunikacija; sustav kontrole kvalitete; edukacija potrošača \\
\hline Dioničari & Visoka & $\begin{array}{l}\text { Edukacije i osposobljavanje; pružanje prilika za napredovanje; sigurnost radnog } \\
\text { mjesta; interna komunikacija; evaluacija zadovoljstva zaposlenika; zdravstveno } \\
\text { osiguranje,osiguranje dobrih radnih uvjeta; nagrade za dobro obavljen posao }\end{array}$ \\
\hline Dobavljači & Visoka/srednja & Generirati veći profit i dobit; zaštita interesa, transparentna komunikacija \\
\hline Zaštita okoliša & Srednja/niska & $\begin{array}{l}\text { Poticanje domaćih proizvođača; transparentnost u poslovanju, posjet dobavljača } \\
\text { plaćanje na vrijeme; edukacija dobavljača prenošenje znanja, otvorena komunikacija }\end{array}$ \\
\hline $\begin{array}{l}\text { Društvo i lokalna } \\
\text { zajednica }\end{array}$ & Visoka/srednja & Pravilno odlaganje otpada; ušteda energije; upotreba ekoloških materijala; recikliranje \\
\hline Mediji & Srednja & $\begin{array}{l}\text { Podrška važnim društvenim projektima; podrška lokalnom stanovništvu i zajednici; } \\
\text { stvaranje novih radnih mjesta; promocija zdravih navika; donacije u sport i kulturu }\end{array}$ \\
\hline $\begin{array}{l}\text { Ne-vladine } \\
\text { udruge }\end{array}$ & Srednja/niska & Informirati društvo, dati informacije za potrošače; istaknuti pozitivne primjere DOP-a \\
\hline Vlada & Srednja/niska & Povezivanje sa školama i fakultetima \\
\hline Konkurencija & Srednja/niska & $\begin{array}{l}\text { Suradnja s vlasti; plaćanje poreza i drugih obveza; lobiranje; zagovaranje javnih } \\
\text { politika }\end{array}$ \\
\hline & & Nema posebnih odnosa, promatranje njihovih postupaka; proizvoda i igre s cijenama \\
\hline
\end{tabular}

Izvor: izrada autora.

su propisane zakonom i koje se odnose na primarne interesno-utjecajne skupine. Gotovo nitko od ispitanih poduzeća nema posebno odgovornu osobu za društveno odgovorno ponašanje, niti planiraju takve aktivnosti. U većini promatranih slučajeva, ideje dolaze spontano, samo s najviše razine, dok je proračun posljednjih godina smanjen zbog gospodarske krize.

„Koliko znam, ne radimo ništa iznad zakonskih okvira... možda samo neki članovi uprave podupiru neke projekte. Nemamo poseban odjel za DOM nego se posao obavlja unutar odjela marketinga. Ideje dolaze spontano, ponekad napravimo brain-storming da odlučimo što ćemo poduprijeti, što nećemo... Uspješnost akcija pratimo samo preko medijskih objava i ponekad preko povratnih informacija zaposlenika. U budućnosti ćemo se više truditi promicati zdraviju prehranu, zdraviji način života... kreirat ćemo nove inovativne proizvod. Smanjili smo proračun zbog krize." (proizvodnja hrane).

„Nije pokrivena suština tj. što je ono što kompanija proizvodi. Postoje kompanije koje imaju savršene izvještaje o DOM-u, velika sponzorstva i donacije, no (prema mom mišljenju) proizvode proizvod koji donosi štetu zdravlju ljudi. Tako da tu dolazimo do apsurda DOM-a. To je možda više filozofsko i etič- no pitanje, no meni osobno je važno jer je upravo područje DOM-a često (ili barem tako izgleda) samoreklamiranje „koliko smo dobri“, ili pak koliko nas kupci natjeraju da mijenjamo svoje obrasce ponašanja... no loš proizvod i dalje ostaje loš proizvod.“ (igre na sreću).

„Nemamo poseban odjel za DOM, a ideje mogu doći samo s najviše razine... nemamo planirane aktivnosti DOM-a niti u dugoročnim planovima. (marketinška agencija).

\subsection{Društveno odgovoran marketing kao odgovor posebnog tima u poduzeću}

Trećina ispitanika koja je sudjelovala u ovom istraživanju provodi društveno odgovorne marketinške aktivnosti iznad zakonski propisane razine. Osim što se u velikoj mjeri brinu o primarno interesnim skupinama (potrošačima, zaposlenicima, dioničarima), također iskazuju kontinuiranu brigu za okoliš, usavršavanje kvalitete proizvoda i procesa proizvodnje, bolje načine povećanja zadovoljstva zaposlenika te društvene zajednice. lako nemaju dugoročne strategije društveno odgovornog marketinga, niti osobe koje bi za to imale posebne odgovornosti, shvaćaju da je to područje na kojem moraju ulagati dosta truda. Motiv koji ih potiče pre- 
ma provođenju društveno odgovornog marketinga jeste pomoć okruženju unutar kojeg žive i rade, te izgradnja boljeg imidža među njima važnim interesno-utjecajnim skupinama.

„S krizom se sve smanjilo, što ne znači nužno da smo radili manje. Dapače, mislim da smo bili „natjerani.“ kreativnošću zamijeniti manja sredstva.“ (promet).

„Naše poduzeće nema zaseban odjel za DOM, nego su aktivnosti isprepletene između menadžmenta i marketinga. Uprava nas podupire i potiče na prihvaćanje i primjenu DOM-a. Poslovne jedinice nisu uključene u davanje ideja DOM-a, samo u njegovu provedbu... Uspjeh mjerimo zadovoljstvom kupaca, tj. porastom prodaje iz godine u godinu." (distributer sanitarne opreme).

„Nemamo jasnu strategiju DOP-a. Ali možda je to i naša prednost jer bi nas papir ograničavao. Ovako smo otvoreni za sve ideje i opcije izvana... često se događa da zaposlenici predstave svoje kreativne ideje. lako smo mi malo tržište, ne znači da je važnost toga što pomažemo mala. Razvijene zemlje imaju puno više aktivnosti i razvijen sustav DOM-a. Kod nas je to potpuno nova tema, mi to radimo iako još uvijek ne moramo, ali osjećamo da smo potrebni našoj zajednici. Sigurna sam da će kroz par godina i u Hrvatskoj to postati normalno." (prodaja robe široke potrošnje).

„Kriza nije utjecala na promjenu stava kompanije o DOM-u, možda smo prije više projekata sufinancirali, a sada dajemo naše proizvode. Mislim da smo dobri u provođenju DOP-a, ali da možemo biti i bolji. Neka poduzeća trebaju biti društveno odgovornija od ostalih, npr.poduzeća koja se bave proizvodnjom alkohola i cigareta. Oni nekako moraju nadoknaditi "štetu" jer proizvode stvari koje upropaštavaju drugoga, moraju se iskupiti za to što rade. Mi ulažemo koliko i oni ulažu, nastojimo biti društveno odgovorni, ne štetimo zajednici. Moraš zajednici u kojoj jesi nešto dati, jer koliko daš, toliko ćeš i dobiti." (proizvodnja hrane).

„Nažalost, zbog krize smo smanjili izdatke vezane za DOM, ali povećali smo aktivnosti u kojima djelatnici doprinose projektima od zajedničkog interesa." (prodaja osiguranja).

\subsection{Društveno odgovoran marketing kao temelj poslovanja poduzeća}

Nekolicina ispitanih vlasnika/menadžera malih i srednjih poduzeća postavila je aktivnosti društveno odgovornog marketinga kao temelj svog poslovanja. Ovako predana poduzeća se razlikuju od prethodno opisanih po tome što su od početka svog poslovanja bila svjesna važnosti društveno odgovornih aktivnosti.Za njih, DOM nije samo inicijativa koja se provodi nekoliko puta godišnje, nego cjelokupna filozofija poslovanja. Ova poduzeća imaju dugoročne planove za društveno odgovorno ponašanje i potiču sve zaposlene da doprinesu svojim idejama. To ne čine zbog vlastite promocije nego što takvo ponašanje određuje njihovo poslovanje. Gotovo sve aktivnosti koje čine nadilaze zakonske propise.

„Početkom naših aktivnosti je počeo i DOM iako ga tako nismo deklarirali. Imamo dosta aktivnosti koje nadilaze zakonske propise, jer in krojimo prema vlastitoj inspiraciji i pogledu a ne samo zbog toga što su zakonski obvezne. Ideje za DOM dolaze od Uprave prema poslovnim jedinicama ali i od djelatnika pa se usvajaju i provode. Mislim da smo uspješni u DOM-u jer sve što radimo, radimo sa strašću. Naši dugoročni ciljevi odgovornog ponašanja su: Biti energetski samodostatni, oslanjati se na obnovljive izvore energije, stvarati što je moguće manje lošeg utjecaja na okoliš, biti podrška civilnom društvu i aktivnostima, razvijati bolji sustav nagrađivanja i motiviranja djelatnika te poboljšavati uvjete njihovog rada, što je moguće više „uvlačit“ kupca kao partnera u poslovanju... Vjerujem da je iz gore iznesenog jasno da nismo baš tipičan primjer DOM-a. Kod mnogih poduzeća u Hrvatskoj dokumenti koji potvrđuju društveno odgovorno ponašanje izgledaju fantastično i mi se ne možemo nositi s time na toj razini. No, zato možemo biti primjer na drugim razinama pa nas evo ovom priliko proglašavam „gerilom“ DOM-a. Ne koristimo DOM kao vlastitu promociju već kao bit našeg postojanja." (proizvodnja i prodaja ekološke hrane).

„DOM je važan jer se $s$ malim sredstvima mogu napraviti velike stvari. Kada drugi vide što mi radimo, ugledaju se u to i krenu raditi nešto slično. Naš motiv za aktivnosti DOM-a je odaziv i suradnja građana. Oni stvarno prepoznaju što mi radimo i to
Brečić, R, Bradica, H., Anđelinović,M.

Primjena društveno odgovornog marketinga u poslovanju malih i srednjih poduzeća 
Brečić, R, Bradica, H., Anđelinović,M.

Primjena društveno odgovornog marketinga u poslovanju malih $\mathrm{i}$ srednjih poduzeća nam daje snagu da idemo dalje. Djelujemo na različitim poljima, bavimo se malo zaštitom okoliša, malo zdravljem... svake godine imamo u planu 3 društveno odgovorne kampanje." (prodaja lijekova).

„U budućnosti ćemo se još jače okrenuti prema ekologiji i kampanjama za zdrav život. Ići ćemo na razvoj djelatnika i naših kupaca. U krizi smo čak povećali izdvajanja za aktivnosti DOM-a. Kada smo mi došli u Hrvatsku i kada bi nekome spomenuli DOP, pitali bi nas što je to... danas ipak pokrećemo neki trend. S vremenom će se taj trend razvijati još i više." (prodaja medicinske opreme).

„Kod hrvatskih poduzeća glavni motiv za DOM je trenutno samo svijest pojedinaca uvjerenih da je takav oblik poslovanja jedini moguć na duge staze... Neodgovorno okruženje (javni i civilni sektor) trenutno ne potiču i ne ohrabruju poduzeća na značajniji iskorak u ovom smjeru... a osim toga educiranost javnosti o ovim temama je vrlo slaba.) $S$ aktivnostima DOM-a smo sustavno započeli prije 20tak godina... to je jednostavno zdravo razumski put, nužan za uspješno poslovanje... sve što radimo je iznad zakona, kod nas nema zakonskih odredbi koje nas navode na takvo ponašanje... DOM najbolje funkcionira kada je prisutna posvećenost top managementa." (građevina).

\section{8. Čimbenici koji utječu na primjenu društveno odgovornog marketinga u malim i srednjim poduzećima}

Predanost malih i srednjih poduzeća društveno odgovornom marketingu razlikuje se na temelju njihove djelatnosti, veličine i ciljeva vlasnika/menadžera. Na temelju rezultata istraživanja, uočeno je kako je značajan čimbenik osobnost vlasnika/ direktora MSP-a (motivi za odgovorno poslovanje) te ljestvice vrijednosti koje slijedi u svom svakodnevnom poslovanju. Pri tome su se kao najčešći motivi spominjali - zaštita potrošača i/ili svih interesno-utjecajnih skupina, doprinos društvu te uvjerenje da je takav način poslovanja jedini koji se uklapa u njihovu životnu filozofiju (temelj rada i djelovanja u društvu). Kao princip ponašanja, menadžeri/vlasnici su razlikovali po tome slijede li

Tablica 4. Čimbenici koji utječu na primjenu društveno odgovornog marketinga u malim i srednjim poduzećima

\begin{tabular}{|c|c|c|c|c|}
\hline \multicolumn{5}{|c|}{ Cimbenici koji utječu na društveno odgovoran marketing } \\
\hline & Djelatnost poduzeća & Veličina poduzeća & Motiv za DOM & Princip ponašanja \\
\hline 1. & Izdavač knjiga & Mala & Zaštita potrošača & Poštivanje zakona \\
\hline 2. & Prodaja automobila & Mala & Zaštita potrošača i okoliša & Poštivanje zakona \\
\hline 3. & Servisna djelatnost & Mala & Zaštita potrošača & Poštivanje zakona \\
\hline 4. & Promet & Srednja & $\begin{array}{l}\text { Zaštita svih interesno-utjecajnih } \\
\text { skupina }\end{array}$ & $\begin{array}{l}\text { Proaktivne inicijative vlasnika, } \\
\text { menadžera }\end{array}$ \\
\hline 5. & Proizvodnja hrane & Srednja & $\begin{array}{l}\text { Zaštita svih interesno-utjecajnih } \\
\text { skupina }\end{array}$ & $\begin{array}{l}\text { Proaktivne inicijative vlasnika, } \\
\text { menadžera }\end{array}$ \\
\hline 6. & Maloprodaja & Mala & $\begin{array}{l}\text { Zaštita svih niteresno-utjecjanih } \\
\text { skupina }\end{array}$ & Poštivanje zakona \\
\hline 7. & Proizvođač hrane & Srednja & $\begin{array}{l}\text { Zaštita svih niteresno-utjecjanih } \\
\text { skupina }\end{array}$ & $\begin{array}{l}\text { Proaktivne inicijative vlasnika, } \\
\text { menadžera }\end{array}$ \\
\hline 8. & Igre na sreću & Srednja & Zaštita potrošača & Poštivanje zakona \\
\hline 9. & $\begin{array}{l}\text { Proizvodnja i prodaja } \\
\text { ekološke hrane }\end{array}$ & Srednja & DOM je temelj poslovanja & $\begin{array}{l}\text { Odgovornost svih prema svim } \\
\text { skupinama društva }\end{array}$ \\
\hline 10. & $\begin{array}{c}\text { Distributer sanitarne } \\
\text { opreme }\end{array}$ & Srednja & Doprinos društvu & $\begin{array}{l}\text { Odgovornost svih prema svim } \\
\text { skupinama društva }\end{array}$ \\
\hline 11. & $\begin{array}{l}\text { Distribucija medicin- } \\
\text { ske opreme }\end{array}$ & Srednja & DOP je temelj poslovanja & $\begin{array}{l}\text { Odgovornost svih prema svim } \\
\text { skupinama društva }\end{array}$ \\
\hline 12. & $\begin{array}{l}\text { Prodaja robe široke } \\
\text { potrošnje }\end{array}$ & Srednja & Doprinos društvu & $\begin{array}{l}\text { Proaktivne inicijative vlasnika, } \\
\text { menadžera }\end{array}$ \\
\hline 13. & Prodaja lijekova & Mala & DOM je temelj poslovanja & Inicijative vlasnika/menadžera \\
\hline 14. & Prodaja osiguranja & Mala & $\begin{array}{l}\text { Zaštita svih interesno-utjecajnih } \\
\text { skupina }\end{array}$ & Poštivanje zakona \\
\hline 15. & Marketinška agencija & Mala & Doprinos društvu & Poštivanje zakona \\
\hline 16. & Građevina & Mala & DOM je temelj poslovanja & $\begin{array}{l}\text { Proaktivne inicijative vlasnika, } \\
\text { menadžera }\end{array}$ \\
\hline
\end{tabular}

Izvor: izrada autora. 
isključivo zakonske propise, implementiraju li dodatne proaktivne inicijative iznad zakona ili svoje cjelokupno ponašanje usmjeravaju u pomoć svim skupinama društva u kojem žive i rade. Pregled odgovora prikazan je u Tablici 5.

\section{Rasprava}

Nakon provedenog istraživanja, ovim radom se došlo do zanimljivih podataka o društveno odgovornom marketingu malih i srednjih poduzeća u Hrvatskoj. Rezultati upućuju na to da su prakse održivosti u malim i srednjim poduzećima još uvijek u fazi uvođenja. Pojam i definicija društveno odgovornog poslovanja je poznata gotovo svim ispitanicima, dok se ne može isto tvrditi za održivi marketing. Vlasnici malih i srednjih poduzeća shvaćaju kako trebaju provoditi praksu koja uzima u obzir očekivanja dionika - potrošača, zaposlenika, dobavljača, lokalne zajednice.

Rezultati ovog istraživanja potvrđuju zaključak Blombacka i Wigrena (2009.) kako se opredjeljenje vlasnika/menadžera malih i srednjih poduzeća na društveno odgovorno ponašanje uglavnom odnosi na operativne aktivnosti, uključuje zaštitu potrošača, korektne odnose prema zaposlenicima te održavanje dobrih radnih odnosa s lokalnim zajednicama.

Što se tiče stupnja razvoja društveno odgovornog marketinga u malim i srednjim poduzećima, tijekom ovog istraživanja izdvojene su tri kategorije poduzeća: poduzeća koja minimalno odgovaraju zahtjevima društveno odgovornog marketinga i štite samo neke od interesno-utjecajnih skupina, poduzeća koju predvodi proaktivni menadžment i koja se trude štiti što više interesno-utjecajnih skupina te poduzeća koja propituju sve svoje odluke u odnosu na odgovorno ponašanje prema društvu i odgovoran marketing čine temelj njihovog poslovanja. Slične kategorije su izdvojili i Russo i Tencati (2009.) te istaknuli kako poduzeća mogu provoditi interne socijalne mjere (zaštita zaposlenika), vanjske socijalne mjere (razvoj lokalne zajednice) i mjere za zaštitu okoliša. Pri tome se uočilo kako je samo nekolicina malih i srednjih poduzeća istaknula važnost zaštite okoliša u svom poslovanju.

Slično kao što su primijetili autori Berger-Douce (2008.) na uzorku malih i srednjih poduzeća u Francuskoj, hrvatska mala i srednja poduzeća u velikoj mjeri imaju dobre veze sa lokalnim zajednicama kroz sponzorstva, kulturna i sportska događanja te poticanje zapošljavanja.

Rezultati ovog rada ukazuju na razlike u primjeni društveno odgovornog marketinga u malim i srednjim poduzećima u odnosu na veličinu poduzeća, djelatnost te ciljeve vlasnika/menadžera. Utvrđeno je kako vizija vlasnika/menadžera u velikoj mjeri utječe na način primjene odgovornog ponašanja u praksi. Baš kao što su 2008. godine istaknuli Spence i sur., društveno odgovoran marketing u malim i srednjim poduzećima uvelike ovisi o osobnom uvjerenju vlasnika/menadžera. Njihova vizija budućnosti poslovanja imat će veliki utjecaj na posvećenost takvom ponašanju.

I dok su Labelle i Saint Pierre (2010.) identificirali tri grupe čimbenika - institucionalni, organizacijski i ljudski, ovim radom poduzeća su podijeljena ovisno o tome poštuju li samo zakonske propise, uvodi li menadžer/vlasnik proaktivne inicijative te je li odgovornost zastupljena prema svim skupinama društva.

Nadalje, potvrđen je zaključak autora Cabagnolsa i Le Basa (2008.) koji su ustanovili pozitivnu vezu između veličine poduzeća i njegove predanosti društveno odgovornom ponašanju. Dokazano je kako su srednja poduzeća više osjetljiva na pitanja društveno odgovornog marketinga od malih poduzeća, a to se pogotovo ističe na području okoliša (Sharma, 2000.). Isto tako, mala poduzeća više su osjetljiva na primarne interesno-utjecajne skupine (potrošači, zaposlenici, lokalna zajednica), dok srednja pokazuju stupanj zainteresiranosti i za sekundarne dionike (dobavljači, konkurencija, mediji...).

Sva istraživanja imaju veći ili manji broj ograničenja pa tako i ovo. Prvo ograničenje odnosi se na dubinski intervju kao izabranu metodu istraživanja. Obrada otvorenih pitanja autoru je predstavljala poseban problem. Autor se suočio s tekstovima koji su međusobno različiti jer svaki čovjek (u ovom slučaju vlasnik/menadžer) ima svoj način izražavanja, redoslijed iznošenja problema, dužinu i opširnost kojom nešto objašnjava. često su spomenute neke stvari koje imaju manje značenje. Nadalje, ljudi višeg obrazovanja i oni koji su otvorenije naravi ili se bolje i lakše izražavaju također su više rekli o promatranom problemu od zatvorenijih tipova ljudi. Prema tome, može se postaviti pitanje pouzdanosti
Brečić, R, Bradica, H., Anđelinović,M.

Primjena društveno odgovornog marketinga u poslovanju malih i srednjih poduzeća 
Brečić, R, Bradica, H., Anđelinović,M.

Primjena društveno odgovornog marketinga u poslovanju malih i srednjih poduzeća rezultata u tome smislu da su možda manje zastupljena mišljenja ljudi koji su sporiji ili su manje vješti u izražavanju (Marušić i Vranešević, 2001.).

Drugo ograničenje istraživanja odnosi se na uzorak malih i srednjih poduzeća. Kako se razlikuju po veličini i broju zaposlenih (od 10 do 250) te po djelatnosti, tako se razlikuje i intenzitet društveno odgovornog marketinga kojeg primjenjuju. Pri tome se moglo dogoditi da su odgovori i primjeri srednjih poduzeća više zastupljeni od malih poduzeća. Nadalje, tijekom istraživanja nije analizirana dinamika razvoja društveno odgovornog marketinga u malim i srednjim poduzéíima.

$\mathrm{Na}$ temelju navedenih ograničenja, za buduća istraživanja izdvaja se nekoliko preporuka. Prvo, bilo bi korisno razumjeti u praksi evoluciju društveno odgovornog marketinga i identificirati faze razvoja društveno odgovornog marketinga korištenjem longitudinalnih studija slučaja.

Nadalje, bilo bi zanimljivo provesti komparativne studije između različitih djelatnosti kako bi se izmjerio utjecaj karakteristika vlasnika/menadžera malih i srednjih poduzeća na aktivnosti koje provode u poslu.

Kao treće, u odnosu na izazove s kojima se susreću mala i srednja poduzeća u provođenju odgovorne strategije, ovim istraživanjem je potvrđeno da nedostatak resursa predstavlja značajnu prepreku. Obećavajući put daljnjeg istraživanja za mala i srednja poduzeća bilo bi ispitivanje povezanosti između financijske održivosti i opredijeljenosti za odgovorno upravljanje. Prema tome, komparativna studija bila bi najprikladnija za ispitivanje mogu li se mala i srednja poduzeća s većim resursima razlikovati u području društveno odgovornog marketinga, od onih s manje raspoloživim resursima.

Konačno, uočena je potreba razvoja edukacije o društveno odgovornom marketingu za vlasnike/ menadžere malih i srednjih poduzeća. U skladu s tim bilo bi potrebno ocijeniti učinke inicijativa i kampanja za podizanje razine svijesti koje su provele različite javne organizacije, ali na transparentniji način nego što je to do sada bio slučaj.

\section{Zaključak}

Mala i srednja poduzeća po svojoj naravi nisu samo umanjena verzija velikih poduzeća, a njihov ekonomski, društveni i ekološki utjecaj na svijet se svakim danom sve više naglašava. Prema tome, potrebno je obratiti posebnu pozornost na specifičnosti društveno odgovornog poslovanja i održivog marketinga malih i srednjih poduzeća. $\mathrm{Na}$ temelju provedenih dubinskih intervjua s 16 vlasnika/menadžera malih i srednjih poduzeća koji posluju u različitim djelatnostima, zaključak ovog rada je kako su većinom upoznati s pojmom i definicijom društveno odgovornog marketinga, ali kako je primjena takvog poslovanja u većini malih i srednjih poduzeća u Hrvatskoj još u začecima. Društveno odgovorne marketinške aktivnosti u najvećoj mjeri su usmjerene prema potrošačima,zaposlenicima i lokalnoj zajednici, dok se ostale interesno-utjecajne skupine (dobavljači, konkurencija, okoliš, vladine organizacije i mediji) spominju tek od strane nekoliko ispitanih malih i srednjih poduzeća. Što se tiče poznavanja principa društveno odgovornog poslovanja i primjene istih u malim i srednjim poduzećima, ovim radom je utvrđeno kako je primjena istih u porastu. lako polovina ispitanih vlasnika/ menadžera slijedi samo zakonske okvire, druga polovina ispitanika ne percipira društveno odgovorno ponašanje kao obvezu, već kao dio njihovog cjelokupnog svakodnevnog upravljanja. Njihove odgovorne primjene mogu se svrstati u tri glavne kategorije: zaštita potrošača i/ili svih interesno utjecajnih skupina, proaktivne inicijative vlasnika/menadžera te odgovorno ponašanje svih prema svim skupinama. Mala i srednja poduzeća se međusobno razlikuju prema stupnju razvoja društveno odgovornog marketinga. $\mathrm{Na}$ temelju razine odgovornosti, dijele se u tri skupine: poduzeća koja minimalno odgovaraju principima društveno odgovornog marketinga, poduzeća koja imaju poseban tim unutar svoje organizacije zadužen za smišljanje i provedbu takvih aktivnosti te poduzeća koja su svoje djelovanje utemeljila na principima održivosti i slijede in u svakoj svojoj odluci i akciji. Postoji nekoliko čimbenika koji stvaraju predispoziciju za predanost primjeni društveno odgovornog marketinga u malim $i$ srednjim poduzećima. Na temelju ovog istraživanja, kao najvažniji među njima ističe se uloga vlasnika/ menadžera malog i srednjeg poduzeća. Nadalje, važna je veličina poduzeća (mikro, malo ili srednje) prema prihodima i broju zaposlenika te djelatnost 
i opseg posla. Pri tome se mala i srednja poduzeća suočavaju s preprekama prilikom usvajanja i provedbe društveno odgovornog marketinga. Slabe točke se ističu u nedostatku sredstava, vremena i znanja (posebno o pitanjima koja se odnose na održivi razvoj). Isto tako, vlasnici/menadžeri malih i srednjih poduzeća često navode kao ograničavajući čimbenik za primjenu odgovornog marketinga, krizu na tržištu te netransparentnost u primjeni zakonskih propisa. Također, preporuke i savjeti za održivi marketing nisu u dovoljnoj mjeri prilagođeni malim i srednjim poduzetnicima. Ovim radom su se istaknuli pozitivni primjeri i posljedice društveno odgovornog marketinga u malim i srednjim poduzećima. Vlasnici/menadžeri su istaknuli mnoge prednosti koje su rezultat primjene održive strategije poslovanja. Primjerice, smanjenje troškova i učinkovitosti koje je donijelo i financijske koristi. Zapravo, pažljivom provedbom i mjerama uštede troškova ili uvođenjem manje štetnih proizvoda za okoliš, mala i srednja poduzeća su smanjila otpad i razvila inovativne proizvode i usluge. Društveno odgovorno ponašanje također omogućuje povećanje motivacije i produktivnosti zaposlenika u malim i srednjim poduzećima. Svjesni izazova koje donosi područje društveno odgovornog marketinga, mala i srednja poduzeća mogu na temelju toga stvoriti konkurentsku prednost i poboljšati svoj imidž.

\section{Literatura}

Albareda, L., Lozano, J. M., Ysa, T. (2007) Public policies on corporate social responsibility: The role of governments in Europe. Journal of Business Ethics, 74(4): 391-407.

Antal, A. B., Sobczak, A. (2007) Corporate social responsibility in France a mix of national traditions and international influences. Business society, 46(1): 9-32.

Basu, K., Palazzo, G. (2008) Corporate social responsibility: A process model of sensemaking. Academy of management review, 33(1): 122-136.

Beckman, T., Colwell, A., Cunningham, P. H. (2009) The emergence of corporate social responsibility in Chile: The importance of authenticity and social networks. Journal of Business Ethics, 86(2): 191-206.

Berger-Douce, S. (2008) Rentabilité et pratiques de RSE en milieu de PME: Premiers résultats d'une étude française. Revue Management et Avenir, 15: 9-29.

Birkinshaw,J., Brannen, M.Y., Tung, R. L. (2011) From a distance and generalizable to up close and grounded: Reclaiming a place for qualitative methods in international business research. Journal of International Business Studies, 42(5): 573-581.

Blombäck, A., Wigren, C. (2009) Challenging the importance of size as determinant for CSR activities. Management of Environmental Quality: An International Journal, 20(3): 255-270.

Boyatzis, R. E. (1998) Transforming qualitative information: Thematic analysis and code development. Sage Publications. California.

Bradica, H. (2016) Aktivnosti društveno odgovornog marketinga u malim i srednjim poduzećima. Ekonomski fakultet Zagreb. Magistarski rad.

Cabagnols, A., Le Bas, C. (2008) The determinants of the behaviour of CSR. Econometric results of a new French survey. Economies et Societes, 42(1): 175.

Carroll, A. B. (1991) The pyramid of corporate social responsibility: Toward the moral management of organizational stakeholders. Business horizons, 34(4): 39-48.

Collins, E., Lawrence, S., Pavlovich, K., Ryan, C. (2007) Business networks and the uptake of sustainability 
Brečić, R, Bradica, H., Anđelinović,M.

Primjena društveno odgovornog marketinga u poslovanju malih $\mathrm{i}$ srednjih poduzeća practices: the case of New Zealand. Journal of Cleaner Production, 15(8): 729-740.

Courrent,J-M. (2004) Ethique et petite entreprise. Revue Française de Gestion, 29(144): 139-152.

Creswell,J.W.(2007) Qualitative inquiry \& research design-Choosing among five approaches (2nd ed.). US: Sage Publications. London.

Déniz, M. D. L. C. D., Suárez, M. K. C. (2005) Corporate social responsibility and family business in Spain. Journal of Business Ethics, 56(1): 27-41.

Du, S., Bhattacharya, C. B., Sen, S. (2010) Maximizing business returns to corporate social responsibility (CSR): The role of CSR communication. International Journal of Management Reviews, 12(1): 8-19.

Ede, F. O., Panigrahi, B., Stuart, J., Calcich, S. (2000) Ethics in small minority businesses. Journal of Business Ethics, 26(2): 133-146.

Ellerup Nielsen, A., Thomsen, C. (2009) Investigating CSR communication in SMEs: a case study among Danish middle managers. Business Ethics: A European Review, 18(1): 83-94.

Elms, H. (2006) Corporate (and stakeholder) responsibility in Central and Eastern Europe. International Journal of Emerging Markets, 1(3): 203-211.

Fassin, Y. (2008) SMEs and the fallacy of formalising CSR. Business Ethics: A European Review, 17(4): 364-378.

Fukukawa, K., Teramoto, Y. (2009) Understanding Japanese CSR: The reflections of managers in the field of global operations. Journal of Business Ethics, 85(1): 133-146.

Gadenne, D. L., Kennedy, J., McKeiver, C. (2009) An empirical study of environmental awareness and practices in SMEs. Journal of Business Ethics, 84(1): 45-63.

Gioia, D. A., Thomas, J. B. (1996) Identity, image, and issue interpretation: Sensemaking during strategic change in academia. Administrative science quarterly, 370-403.

Gond,J. P., Igalens,J. (2008) La responsabilité sociale de l'entreprise. Presses universitaires de France.

Hammann, E. M., Habisch, A., Pechlaner, H. (2009) Values that create value: socially responsible business practices in SMEs-empirical evidence from German companies. Business Ethics: A European Review, 18(1): 37-51.

Hemingway, C. A. (2005) Personal values as a catalyst for corporate social entrepreneurship. Journal of business ethics, 60(3): 233-249.

Jamali, D., Mirshak, R. (2007) Corporate social responsibility (CSR): Theory and practice in a developing country context. Journal of business ethics, 72(3): 243-262.

Jenkins, H. (2004) A critique of conventional CSR theory: An SME perspective. Journal of general Management, 29: 55-75.

Jenkins, H. (2006) Small Business Champions for Corporate Social Responsibility. Journal of Business Ethics, 67: 241-256.

Jenkins, H. (2009) A 'business opportunity' model of corporate social responsibility for small-and medium-sized enterprises. Business ethics: A European review, 18(1): 21-36.

Juholin, E. (2004) For business or the good of all? A Finnish approach to corporate social responsibility. Corporate Governance: The international journal of business in society, 4(3): 20-31.

Kechiche, A., Soparnot, R. (2012) CSR within SMEs: Literature review. International Business Research, 5(7): 97.

Keller, K. L., Kotler, P. (2005) Marketing Management. Inglewood.

Labelle, F., St-Pierre,J. (2010) Les déterminants institutionnels, organisationnels et individuels de la sensibilité des PME au sujet du développement durable. 
Laczniak, G. R., Murphy, P.E.(2006) Normative perspectives for ethical and socially responsible marketing. Journal of Macromarketing, 26(2): 154-177.

Lepoutre, J., Heene,A. (2006) Investigating the impact of firm size on small business social responsibility: A critical review. Journal of business ethics, 67(3): 257-273.

Lin-Hi, N., Müller, K. (2013) The CSR bottom line: Preventing corporate social irresponsibility. Journal of Business Research, 66(10): 1928-1936.

Marušić, M., Vranešević, T. (2001) Istraživanje tržišta. Adeco.

Mathieu, A. L., Reynaud, E. (2005) Les bénéfices de la responsabilité sociale de l'entreprise pour les PME: entre réduction des couts et légitimité (No. hal-01796497).

McCracken, G. (1988) The long interview (Vol. 13). Sage Publications. London.

McShane, L., Cunningham, P. (2012) To thine own self be true? Employees' judgments of the authenticity of their organization's corporate social responsibility program. Journal of business ethics, 108(1): 81-100.

Midttun, A., Gjølberg, M., Kourula, A., Sweet, S., Vallentin, S. (2012) Public Policies for Corporate Social Responsibility in Four Nordic Countries. Business \& Society, 54(4): 464-500.

Miles, M. B., Huberman, A. M. (1984) Drawing valid meaning from qualitative data: Toward a shared craft. Educational researcher, 13(5): 20-30.

Murillo, D., Lozano,J.M. (2006) SMEs and CSR: An approach to CSR in their own words. Journal of Business Ethics, 67(3): 227-240.

Murillo, D., Lozano,J.M. (2009) Pushing forward SME CSR through a network: an account from the Catalan model. Business Ethics: A European Review, 18(1): 7-20.

Öberseder, M., Schlegelmilch, B. B., Murphy, P. E. (2013) CSR practices and consumer perceptions, Journal of Business Research 20(10): 1839-1851.

Omazic, M. A., Banovac, K. (2012) Internet based overview of corporate social responsible practice in four countries in Southeast Europe. International Journal of Management Cases, 14(3): 72-80.

Pejić Bach, M., Ante Omazić, M., Zoroja, J. (2015) Transparency as a precondition of systemic behavior: The case of European retailing banks regarding social responsibility communication. Systems Research and Behavioral Science, 32(2): 256-264.

Pohle, G., Hittner, J. (2008) Attaining sustainable growth through corporate social responsibility. IBM Institute for Business Value, 20.

Porter, M. E., Kramer, M. R. (2006) The link between competitive advantage and corporate social responsibility. Harvard business review, 84(12): 78-92.

Quairel, F.,Auberger, M. N. (2007) La diffusion de la RSE par la relation fournisseurs: injonctions paradoxales ou partenariat de progrès?. Revue internationale PME: Économie et gestion de la petite et moyenne entreprise, 20(3-4): 69-94.

Razum, A. (2015) Održivi marketing kao odrednica poslovne uspješnosti. Ekonomski fakultet Zagreb, Sveučilište u Zagrebu. Doktorska disertacija.

Revell,A., Blackburn, R. (2007) The business case for sustainability? An examination of small firms in the UK's construction and restaurant sectors. Business Strategy and the Environment, 16(6): 404-420.

Russo, A., Tencati, A. (2009) Formal vs. informal CSR strategies: Evidence from Italian micro, small, medium-sized, and large firms. Journal of Business Ethics, 85(2): 339-353.

Saulquin, J. Y., Schier, G. (2007) Des perceptions managérials aux pratiques RSE: une étude exploratoire. Gestion 2000, 24(6).

Saulquin, J-Y., Schier, G. (2010) Performance organisationnelle et responsabilité sociale de l'entreprise. In Dion, M. Wolff, D. (EdS.): Le développement durable, théories et applications au management, Ed. Dunod, 
Brečić, R, Bradica, H., Anđelinović,M.

Primjena društveno odgovornog marketinga u poslovanju malih $\mathrm{i}$ srednjih poduzeća 2ème Ed., 127-142.

Sharma, S. (2000) Managerial interpretations and organizational context as predictors of corporate choice of environmental strategy. Academy of Management journal,43(4): 681-697.

Skarmeas, D., Leonidou, C. N. (2013) When consumers doubt, watch out! The role of CSR skepticism. Journal of Business Research, 66(10): 1831-1838.

Sobczak, A., Havard, C. (2015) Stakeholders' influence on French unions' CSR strategies. Journal of Business Ethics, 129(2): 311-324.

Spence, L. J. (1999) Does size matter? The state of the art in small business ethics. Business ethics: a European review, 8(3): 163-174.

Spence, L.J. (2007) CSR and small business in a European policy context: the five "C" s of CSR and small business research agenda 2007. Business and society review, 112(4): 533-552.

Spence, L. J., Lozano, J. F. (2000) Communicating about ethics with small firms: Experiences from the UK and Spain. In Business Challenging Business Ethics: New Instruments for Coping with Diversity in International Business (pp. 43-53). Springer Netherlands.

Spence, L.J., Habisch,A., Schmidpeter, R. (Eds.). (2004) Responsibility and social capital: The world of small and medium sized enterprises. Palgrave Macmillan. London.UK.

Spence, L. J., Schmidpeter, R., Habisch, A. (2003) Assessing social capital: Small and medium sized enterprises in Germany and the UK. Journal of Business ethics, 47(1): 17-29.

Spence, M., Biwolé, V. O., Ben Boubaker Gherib, J. (2007) Une étude exploratoire du degré d’engagement des PME dans le développement durable. Proceedings of the 10th Scientific Days of the Entrepreneurship Network of the AUF, Antananarivo, 23-26.

Torrès, 0. (2000) Du rôle et de l'importance de la proximité dans la spécificité de gestion des PME. Sème Congrès International Francophone PME, (CIFPME): Lille, octobre.

Torrès, 0. (2003) Petitesse des entreprises et grossissement des effets de proximité. Revue Française de Gestion,(144): 119-138.

Vives,A. (2006) Social and environmental responsibility in small and medium enterprises in Latin America. Journal of Corporate Citizenship, 2006(21): 39-50.

Worthington, I., Ram, M., Boyal, H., Shah, M. (2008) Researching the drivers of socially responsible purchasing: a cross-national study of supplier diversity initiatives. Journal of Business Ethics, 79(3): 319-331. 